\title{
Pastores da cura: historiografia de discursos e intervenções médico- criminológicas sobre a homossexualidade no Brasil (1930-1940)
}

\author{
Pastors of healing: historiography of discourses and medical-criminological \\ interventions on homosexuality in Brazil (1930-1940)
}

Juliana Ferreira da Silva; Luender Rytchell Martins Silva

Universidade Católica de Brasília

\section{RESUMO:}

O estudo parte dos trâmites parlamentares ocorridos entre 2009 e 2013, quando se discutiu a possibilidade de psicólogos intervirem na orientação sexual de sujeitos homossexuais. $\mathrm{O}$ trabalho discute atravessamentos morais religiosos no campo da psicologia e na esfera da política republicana, propondo uma narrativa histórica das intervenções médicas e psicológicas sobre a homossexualidade no Brasil, com recorte no período 1930-1940. Argumenta-se que essa disputa no campo psi evidencia dispositivos de controle sobre os modos de existência contra-hegemônicos, que reatualizam lógicas de funcionamento dos saberes psiquiátrico e criminológico do início do século XX. Conclui-se que as tentativas de captura da psicologia, enquanto saber-poder posto a serviço da repatologização da homossexualidade explicitam um projeto de poder mais abrangente, cujas tecnologias estão relacionadas ao exercício do poder pastoral.

Palavras-chave: homossexualidade; degenerescência; governamentalidade

\begin{abstract}
:
The study starts from the parliamentary procedures that took place between 2009 and 2013, when the possibility of psychologists to intervene in the sexual orientation of homosexual subjects was discussed. This paper discusses religious moral crossings in the field of psychology and in the sphere of republican politics, proposing a historical narrative of medical and psychological interventions on homosexuality in Brazil, with a cut in the 1930-1940 period. It is argued that this dispute in the psychological field highlights devices of control over the ways of counter-hegemonic existences, which update the logic of the functioning of psychiatric and criminological knowledge at the beginning of the 20th century. It is concluded that the attempts to capture psychology, as knowledge-power put at the service of the repathologization of homosexuality, explain a more comprehensive power project, whose technologies are related to the exercise of pastoral power.
\end{abstract}

Key-words: homosexuality; degeneration; governmentality. 


\section{Introdução}

As violências incididas sobre pessoas homossexuais ganham destaques nos debates acadêmicos contemporâneos e nas discussões sobre medidas que visam a proteção dos indivíduos que se encontram em situação de vulnerabilidade em relação a discriminações e violências homofóbicas. A psicologia, enquanto ciência e profissão, ocupa um lugar nesse cenário por oferecer um olhar sobre as subjetividades e as coletividades, abarcando, dentre outros temas, os efeitos das violências nos psiquismos e na estrutura social (MARTINS \& LACERDA JR., 2018). Entretanto, nos debates contemporâneos sobre a sexualidade, a psicologia tem sido convidada a discursar sobre outra questão: a gênese da homossexualidade.

Através de uma conjunção política e religiosa, a última década explicitou uma demanda por descobrir e explicar as causas da homossexualidade, acompanhada do delineamento de intervenções supostamente terapêuticas que visassem a reorientação sexual (GAMA, 2019). Essa pauta direcionada à Psicologia produziu cisão entre psicólogas/os, ainda que em grupos quantitativamente distintos. As atuais investidas que buscam a legitimação das intervenções sobre a orientação sexual acompanham também um crescente movimento conservador cristão, evangélico em sua maioria, seja no cenário político, seja no próprio corpo profissional da Psicologia (CFP, 2019). Dessa forma, o cenário desses debates sobre a homossexualidade passa a incluir a discussão sobre a laicidade da Psicologia. Vale ressaltar que não se propõe aqui uma crítica sobre a religiosidade dos psicólogos nem dos sujeitos que ocupam cargos políticos. Há, antes, uma problematização sobre as investidas no campo do saber psi, que expressa a preocupação com a defesa de princípios do exercício profissional que podem ser ameaçados a partir dos atravessamentos morais religiosos na profissão. Sobre esse ponto, faz-se importante destacar que o código de ética da profissão, alicerçado na defesa dos direitos humanos, diferencia as ações éticas e antiéticas, tomando como princípio fundamental da profissão a eliminação de quaisquer formas de negligência, discriminação, exploração, violência, crueldade e opressão (CFP, 2005). Assim sendo, o debate interno da categoria implica na afirmação de que psicólogas/os que oferecem e defendem intervenções que visem a reorientação sexual estão atuando de maneira ilegítima frente aos acordos epistemológicos firmados coletivamente na profissão. Ainda assim, essa pauta de "cura" é não somente dirigida à psicologia, mas também recepcionada por alguns de seus profissionais, posto que a psicologia em si mesma - longe de ser solo serenado - constitui um território em disputa.

O endereçamento à psicologia da demanda por descobrir as causas, explicar e reorientar a homossexualidade terá papel central neste trabalho. Propõe-se discutir historicamente tal 
demanda, mostrando que há recorrência nessa pauta, o que configura certo retorno de investidas do saber $p s i$ sobre a sexualidade na direção da normatização. A palavra "retorno" alude às raízes dos estudos sobre a homossexualidade no Brasil e as consequentes intervenções ocorridas. $\mathrm{O}$ saber médico e psicológico, em décadas passadas, apresentou explicações e realizou intervenções que almejavam a reorientação sexual. Ademais, tais investidas do saber psi sobre a homossexualidade foram acompanhadas de políticas públicas de justiça criminal, fazendo com que homossexuais fossem, além de objeto da medicina, também criminalizados pelos poderes executivo e judiciário. Principalmente após a década de 1930, a criminologia brasileira discursou sobre a predisposição dos homossexuais a transgredirem leis. Sodomita, degenerado, invertido e pederasta foram alguns dos termos utilizados para se referir aos sujeitos homossexuais.

A perspectiva deste trabalho parte do entendimento de que os acontecimentos contemporâneos apresentam ressonâncias de produções, discursos e práticas que estiveram presentes outrora. A partir da leitura da obra de Certeau (1982), depreende-se que a história está longe de ser o estudo das sucessões dos fatos em uma linha cronológica pontilhada de datas marcantes. A prática historiográfica é uma produção e destina-se à compreensão das inteligibilidades. Respeitando as diferenças e desvios encontrados entre os acontecimentos presentes e passados, pergunta-se sobre os enlaces que constituem uma narrativa dos ecos encontrados em documentos, instituições, discursos e dispositivos. Em consonância com esse pensamento, este trabalho também aposta que, na atualidade, os jogos discursivos em torno da suposta cura da homossexualidade perpassam entendimentos historicamente construídos incorporados às instituições médicas, psicológicas e jurídicas. Pretende-se demonstrar que não é uma coincidência que a psicologia esteja ocupando lugar central nos debates hodiernos sobre a "cura gay". A partir da narrativa sobre trajetórias históricas da discussão acerca da homossexualidade na psicologia e psiquiatria no Brasil, propõe-se mostrar que o saber psi esteve presente na busca pela gênese da homossexualidade e maquinou para que a homossexualidade ganhasse caráter de inteligibilidade enquanto desvio patológico.

\section{$O$ analisador: a pauta da cura da homossexualidade nas disputas em torno da psicologia}

Em 2009, o Conselho Federal de Psicologia (CFP) censurou publicamente a psicóloga Rozangela Alves Justino por oferecer assim chamado "tratamento de reorientação sexual" para homossexuais, algo que era expressamente proibido pelos artigos $3^{\circ}$ e $4^{\circ}$ da Resolução CFP $n^{\circ}$ 001/1999, documento que desautorizava atuação profissional que levasse à patologização de 
práticas ou comportamentos homoeróticos e/ou a participação em eventos ou meios de comunicação que promovessem o preconceito social contra homossexuais (CFP, 1999, p. 02; GAMA, 2019, p. 03). Com a repercussão do caso, o deputado Cel. Paes de Lira (PTC/SP) entrou com o Projeto de Decreto Legislativo (PDC) no 1640/2009, com o objetivo de suspender os referidos artigos que, para ele, restringiam o exercício da profissão e atentavam contra a liberdade de expressão. O decreto foi arquivado em dezembro de $2010 \mathrm{com}$ o término da $53^{\circ}$ legislatura, não sendo desarquivado na legislatura subsequente. Em 2011, o deputado João Campos (PSDB/GO), presidente da Frente Parlamentar Evangélica, apresentou o PDC $\mathrm{n}^{\circ}$ 234/2011 que objetivou a sustação dos mesmos artigos. Os trâmites desta PDC foram mais prolongados e duraram até 2013. Neste segundo momento, havia maior quantitativo de parlamentares que integravam a bancada evangélica, inclusive na liderança de comissões que discutem temas como família, moralidade e sexualidade, como a Comissão dos Direitos Humanos e Minorias e a Comissão de Família e Seguridade Social (GAMA, 2019, p. 14). O PDC foi retirado de tramitação pelo próprio autor, que alegou ausência de apoio pelo seu partido. Para a pronunciação nos trâmites parlamentares que discutiram o PDC 234/2011, foram convidados como psicólogos Marisa Lobo e Silas Malafaia, ambas figuras políticas que têm cargos oficiais no legislativo e também cargos na Igreja Assembleia de Deus, mas que, naquele espaço político de debate do projeto, falavam em nome de suas formações profissionais como psicólogos. Neste caso, falando em nome da psicologia que exercem, defenderam que as pessoas LGBTIs demandariam serviços de clínica psicológica e demonstrariam sofrimento psíquico - sofrimento este que era entendido por esses psicólogos como decorrente da identidade de gênero ou orientação sexual das pessoas LGBTIs. Argumentaram que essas pessoas em sofrimento têm o direito de receber tratamento de reorientação que modifique seu comportamento homoerótico. Tais acontecimentos geraram reação no âmbito da psicologia, formando um debate interno à categoria sobre o tratamento popularmente conhecido como “cura-gay". Embora ganhe intensidade nas redes sociais digitais e tenha angariado espaço de fala no legislativo, o grupo de psicólogas(os) que propõe tais práticas supostamente psicoterápicas não representa o posicionamento majoritário da categoria.

Essa é a pauta que se explicita no dia 02 de junho de 2019, em Brasília, quando ocorreu o $10^{\circ}$ Congresso Nacional de Psicologia (CNP). O congresso constitui a instância máxima de um processo deliberativo que envolve toda a categoria com uma metodologia de participação democrática acerca das políticas prioritárias de atuação dos Conselhos Regionais e do Federal de Psicologia para o triênio subsequente. Diferentemente de um congresso acadêmico, o CNP 
é um espaço de definição da contribuição do Sistema Conselhos para o desenvolvimento da psicologia e conta com as deliberações dos eventos anteriores realizados pelos Conselhos Regionais. Por ser também um espaço de articulação de proposituras, no CNP ocorrem a inscrição e apresentação de chapas que concorrerão aos mandatos dos Conselhos Regionais e Federal de Psicologia no triênio subsequente (CFP, 2019). Durante o CNP de 2019, as chapas que concorriam para a gestão nacional do CFP apresentaram suas propostas. No momento do discurso da psicóloga Rozangela Alves Justino, representante da chapa Movimento Psicólogos em Ação (MPA), a maior parte dos demais psicólogos deram as costas e, em alguns momentos, também vaiaram. Além disso, alguns deles também ergueram a bandeira LGBT. Para a chapa MPA, a ações enquadram-se em uma conduta antiética, desrespeitosa e partidária. Em contrapartida, psicólogas/os que adotaram essa postura alegaram a necessária demonstração de repúdio e resistência diante do discurso que, para eles, difunde a "cura-gay" como possibilidade de atuação do profissional da psicologia.

\section{O campo de forças}

O fato analisador (BAREMBLITT, 1996) expõe a disputa em torno da laicidade da psicologia, o que não pode se separar de uma disputa que se dá também em torno do poder político nas esferas do legislativo, executivo e judiciário. Há, portanto, o conflito entre a afirmação de uma psicologia laica contra o avanço de discursos religiosos nesse campo de saber, ao passo que se observa também preocupação social quanto à ocupação de cargos do poder público por figuras representativas de instituições religiosas - sobretudo as assim denominadas igrejas evangélicas. Assim, da mesma forma pela qual se debate o discurso religioso na psicologia também se debate o poder alcançado pela bancada evangélica no Congresso Nacional.

Conforme apontado na sequência dos acontecimentos, a questão religiosa esteve totalmente articulada com os trâmites parlamentares discutidos, ainda que o objeto de pauta fosse o exercício da ciência - no caso, a psicologia. A crítica que se faz hodiernamente à inserção do discurso religioso na esfera política pode ser melhor compreendida em se considerando a formação do governo republicano moderno. Em síntese, a república moderna é o projeto político de divisão do poder entre o governo das almas e o governo dos homens. $\mathrm{O}$ conceito de potestas, que significa potência, ganha papel central na obra de Jean Bodin, $A$ República, ao definir o estatuto daquilo que pode. Refere-se a uma distinção qualitativa de um campo de possibilidades. No Império Romano, a potestas pertencia ao Imperador e ele tudo 
podia. Essa ideia foi incorporada na constituição da Igreja Católica, que, através de um processo de sacralização, transfere a potestas para Deus. Portanto, o divino passou a ser a única potência soberana. A partir da institucionalização do papado, o Papa torna-se o representante da potestas de Deus entre os indivíduos, cabendo a ele administrar a palavra divina. Dessa forma, instaurase uma disputa entre as duas instâncias, tendo em vista que ocupar o lugar de potestas ou o lugar de tradutor de uma potestas divina significava a garantia de um poder assimétrico sobre os indivíduos. Há aqui o contraste entre a laicidade do imperador romano e a liturgia católica assentada na potência divina. A ideia de Jean Bodin sobre a potestas abriu margem para que o Estado alcançasse soberania (CHÂTELET, 1992).

As revoluções burguesas dão curso a reformulações do Estado, instaurando na teoria política a ideia de soberania legítima. Os contratualistas sustentam a ideia de que o governo soberano é fundado na necessidade de regular as liberdades individuais tendo em vista a coletividade, ainda que defendam teses adversárias sobre os pressupostos que fundamentam a legitimidade do Estado - vide a diferença entre o pensamento de Hobbes e Locke. Afirmam que o poder do Estado em restringir a liberdade individual é condição necessária para a própria existência individual. A sociedade é concebida como construto capaz de instaurar uma ordem coletiva à qual os indivíduos serão subordinados para que cada um seja protegido em sua individualidade. Assim, a sociedade requer um governo que tem como limite radical não exigir dos indivíduos nada a mais do que o necessário para a garantia dessa coletividade. Dessa forma, o exercício da liberdade individual só pode ser cerceado na medida em que este coloque em xeque a sobrevivência coletiva e nada mais, "o Estado nunca pode exigir de alguém que não seja quem é” (CHÂTELET, 1992: 86). A constituição do governo republicano a partir da Revolução Francesa separa de maneira explícita o discurso religioso da esfera política. Ao poder civil, instaurado pela República, é garantido o exercício do governo dos vivos, enquanto que ao poder religioso, instaurado na figura das igrejas, é facultado o exercício do governo das almas. Portanto, laicidade é a marca do Estado republicano, que regula as liberdades na esfera pública, e religiosidade é circunscrita à esfera individual (CHÂTELET, 1992).

A divisão dá-se entre duas instâncias de exercício do poder. O governo das almas, que opera pela lógica do poder pastoral, como a dinâmica instaurada pelo cristianismo, realiza uma economia dos méritos e deméritos dos indivíduos. O poder pastoral assenta-se no princípio da salvação após a morte, outorgando ao pastor a responsabilidade de garantir comportamentos, pensamentos e modos de vidas que coadunem com os requisitos que asseguram a salvação da alma de cada súdito. Essa salvação está alicerçada na máxima de que os méritos devem sobrepor 
os deméritos a partir dos preceitos da religião cristã. Dessa forma, a metáfora do pastor e das ovelhas presente nas passagens bíblicas ilustra o quadro instituído pelo cristianismo ao nomear indivíduos que guiam e indivíduos que são guiados. Nessa dinâmica, a vontade de Deus é o único norte a ser seguido, ainda que tal norte seja impositivo, posto que é racionalmente insondável. Os súditos entram em um campo de concessões de vontades, tornando-se integralmente dependentes do poder pastoral, pela via dos discursos de verdade que direcionam sua conduta cotidiana e solicitando direções para a própria consciência. O poder pastoral inaugurou, no ocidente, a arte de governar, ao inserir práticas de poder que delinearam as condutas humanas desejadas de forma integral e compulsória (FOUCAULT, 2005).

A partir do século XVI, verifica-se a gradual "desgovernamentalização do cosmo" (FOUCAULT, 2008a). Isso significa o enfraquecimento do antropocentrismo através da inserção de saberes que decifraram o ordenamento da natureza a partir das leis da matemática e da física. Anteriormente a isso, a natureza falava a partir das vontades de Deus, o Grande Pastor da humanidade, que enviava sinais de descontentamento ou aprovação. Essa mudança de racionalidade impõe novas responsabilidades ao soberano, tendo em vista a destituição da função de representante das leis divinas na Terra. Nas repúblicas, os Estados incorporam a arte de governar os homens para garantir a integridade do domínio territorial, jurisdição, instituição e estatuto dos indivíduos (FOUCAULT, 2008a). Assim sendo, a política é uma organização do poder que circula no Estado, um produto da governamentalidade, entendendo-a como o conjunto de procedimentos que visam a condução dos indivíduos e da população.

O processo de constituição da República no Brasil não tem a mesma trajetória da europeia. A abolição da escravidão resultou em uma ruptura entre a Coroa e os proprietários rurais (CARVALHO, 2008, p. 122). Esses sujeitos, que reivindicaram indenizações diante da perda da mão de obra escravizada, associaram-se ao movimento republicano para alcançar compensações que vislumbraram nessa forma de governo. Nesse processo, a Monarquia ganhou novos inimigos e perdeu força nas decisões governamentais após o enfraquecimento dos partidos monárquicos. Outro fator fundamental para a Proclamação da República no Brasil foi a proximidade dos militares com o movimento abolicionista e com os pensamentos republicanos (CARVALHO, 2008). O golpe militar que proclamou a República ocorreu a partir da conspiração das forças armadas que adicionaram ao pensamento militar os ideais positivistas e republicanos. A Primeira República (1889-1930) não promoveu a soberania popular e tampouco diminuiu as discrepâncias entre as classes no Brasil. As elites conservaram o poder político através de dinâmicas de revezamento entre os estados que mais produziam riquezas (BETHELL, 2012). 
Hodiernamente, diversos sujeitos que ocupam lugares no âmbito político brasileiro apresentam-se como representantes de códigos morais religiosos - majoritariamente cristãos evangélicos -, objetivando a inserção destes códigos no aparato legislativo (SILVA, 2017). A transparência em que se dá essa inserção parece indicar um projeto de retorno do governo das almas sobre a vida dos vivos em uma conjuntura política. Mas, se isso se dá na vigência de uma constituição de poder republicana, resta saber por quais dispositivos essa investida do poder religioso pretende alcançar o poder político. Por quais meios, ou melhor, a partir de quais enlaces e tecnologias pode o poder religioso capturar o poder político novamente?

\section{O prisma teórico: vontade de potência e vontade de curar}

Nietzsche dedicou boa parte da sua obra apontando os efeitos dos regimes da moral e da religião sobre a vida. Para o autor, tais regimes impediam que a vida se afirmasse enquanto tal, impossibilitando modos de vida singulares que rompem os ditames morais. O filósofo também criticava as metafísicas que afastavam os indivíduos da imanência e consequentemente do próprio corpo. Especificamente sobre a religião, Nietzsche expressou sua indignação em relação aos discursos que reivindicavam a posse de verdades absolutas que separavam o mundo entre os "eleitos" e os demais (FERRAZ, 1994). A ética nietzschiana está concentrada no imperativo “Torna-te quem tu és". De acordo com ele, o processo de "tornar quem és" dependeria de explorações que alimentariam o conhecimento de si, de potências e fraquezas, para a construção de mapas de forças que promoveriam a afirmação da vida. Importante frisar que o filósofo criticava códigos morais universais. Dessa forma, defendeu um modo de vida singular que afirma apenas a própria existência. Deleuze (1976) relê o conceito de Nietzsche, assumindo que a vontade de potência introduz uma genealogia nas relações de força. Ao falar do corpo, seja ele químico, biológico ou social, ele o conceitua como relações entre forças ativas e reativas. A força será ativa quando for superior e dominante na relação que compõe com as forças reativas, inferiores e dominadas. Nesse contexto, a vontade de potência aparece como o elemento que introduz uma sensibilidade na relação entre as forças ao qualificá-las e acrescentar, nessa dinâmica, os possíveis devires. A vontade de potência, em suma, é a ânsia de afirmação da vida que, opondo-se às obrigações morais, engendra a potencialização dos devires. Assim, desde tal perspectiva, os discursos moralizantes hodiernos rivalizam com a vontade de potência e criam barreiras para existências singulares (DELEUZE, 1976).

Em 2019, o CFP organizou o livro Tentativas de Aniquilamento de Subjetividades LGBTIs. A obra versa sobre os sofrimentos ético-políticos que atravessam a vivência dos 
indivíduos que integram a comunidade LGBTIs, englobando as diversas violências e as resistências engendradas a partir da necessidade de viver em um país que nega expressões de alteridade. O trecho a seguir exemplifica a captura delineada por alguns psicólogos que, contrariando o Código de Ética da profissão, repatologizam a homossexualidade através dos pressupostos do funcionamento psíquico:

Ele (o psicólogo) dizia que a minha homossexualidade teria advindo de uma relação inadequada com o meu pai. Segundo ele, quando a criança do sexo masculino deixava de se identificar com pai, ou se o relacionamento da criança com pai fosse um relacionamento ruim, ele não iria conseguir se identificar com o masculino e, portanto, ia passar a buscar esse masculino em outros homens. À medida que isso não acontecesse, se tornaria um desejo sexualizado, e daí (surgiam) os desejos homossexuais. Então, era uma sensação de insuficiência na minha masculinidade, na visão dele, que causaria essa busca, esses desejos homossexuais. (CFP, 2019: 59).

Diante do exposto, é possível refletir sobre os conjuntos de saberes e práticas profissionais que buscam afirmação, efetivação e dominação de outras formas de conhecimentos e que produzem intervenções coisificantes. Também é possível pensar nas diversas formas de vida que sofrem tentativas de aniquilamento quando não coadunam com as vivências hegemônicas. Como parte de uma tecnologia de poder sobre as vivências singulares, observa-se, no mínimo, o investimento na precarização das vidas que destoam das identidades e sexualidades normatizadas. Neste trabalho, tal projeto de normalização receberá a denominação vontade de curar, com a qual se quer dizer que ela contraria a vontade de potência, porque está alicerçada em pressupostos morais que bloqueiam experiências de vidas singulares e engendram intervenções normatizantes.

A história da homossexualidade no Brasil precisa ser revisitada para fazer-se mostrar como é marcada por violências físicas e morais engendradas pela vontade de curar por meio de discursos médicos e criminológicos. Numa sociedade tão vigilante sobre os usos dos prazeres, é preciso desnudar - posto que o nu provoca - os processos de articulação do saber psicológico com as tentativas de imprimir patologias em sujeitos que fogem da matriz heteronormativa. Tendo como ponto de partida o atual debate acerca da cura-gay, foram buscados nesses discursos os antecedentes da vontade de curar no Brasil. A pesquisa historiográfica pautou-se na proposta de analisar de que forma os discursos sobre a cura da homossexualidade emergiram no contexto da criminologia, tendo como recorte histórico o período de 1930 a 1960. Tal delimitação cronológica justifica-se pela ampla articulação entre os saberes psicológicos e criminológicos evidenciados nessa época (FERLA, 2005). 


\section{Homossexualidade e degenerescência: um recorte da vontade de curar no Brasil}

O estudo das transgressões das leis deteve-se sob duas óticas. A primeira, discutida pela Escola Clássica, destacou a ação como objeto de estudo, entendendo o crime como ruptura do contrato social. Esta perspectiva, alicerçada na noção de livre-arbítrio, defendeu a punição para as ações criminosas. A segunda ótica, defendida pela Escola Positivista, enfatizou o criminoso em detrimento do crime. Através desta perspectiva, o crime indicava um sintoma da patologia do indivíduo, originada na estrutura bio-antropológica. Cesare Lombroso (1835 - 1909) foi um dos autores mais influentes desta racionalidade e, a partir dele, muito foi produzido em consonância com o objetivo de estudar as predisposições dos indivíduos ao crime, entendido como um desvio da norma social natural (FERLA, 2005).

Um argumento muito utilizado nos debates parlamentares do PDC $n^{\circ}$ 234/2011 versava sobre a iminência da destruição familiar como consequência da homossexualidade. Essa alegação não é nova e está totalmente relacionada ao olhar normatizador que se debruça sobre os formatos familiares. O trecho a seguir, escrito em 1938 por Aldo Sinisgalli, explicita essa lógica:

O homossexualismo é anti-social. $O$ homossexualismo é a destruição da sociedade, é o enfraquecimento dos países. Compreende-se facilmente o prejuízo que traz à sociedade e às nações o desenvolvimento do homossexualismo, sabendo-se que os invertidos encontram satisfação genésica com indivíduos do mesmo sexo, desprezando as mulheres. A maioria dos pederastas não se casa, não constitui família. A grande maioria é constituída por moços solteiros. Portanto, o pederasta não contribui para o engrandecimento, para o desenvolvimento da sociedade e do país. Se o homossexualismo fosse regra, o mundo acabaria em pouco tempo. (SINISGALLI, 1938, citado por GREEN \& POLITO, 2004: 101)

Destaca-se o uso da palavra "destruição" que alude a um perigo que está internalizado no próprio ser do qual se fala, no caso os homossexuais. Não há argumentos sobre a constituição biopsicológica destes; entretanto, o autor parece incluir estes sujeitos em um grupo que coloca em risco a vida em sociedade.

A perversão sexual esteve presente na classificação nosológica de Bénédict-Augustin Morel. A degeneração, conceito proposto por Morel, articulava os aspectos físicos com os aspectos morais, unificando a análise dos indivíduos e inaugurando a crença da hereditariedade mórbida (FERLA, 2005). Na obra Psiquiatria clínica e Forense, de 1940, Antônio Carlos Pacheco e Silva inclui o "homossexualismo" na lista de perversões sexuais ao lado de sadismo, masoquismo, necrofilia, bestialismo, exibicionismo, frigidez, ninfomania, satiríase e onanismo. Para o autor, o homossexual era um perigo social (PACHECO e SILVA, 1940, citado por GREEN \& POLITO, 2004: 81). 
Assim constituído, tal perigo social deveria ser propriamente controlado. Portanto, o Código Penal de 1940 contou com uma proposta de artigo (n. 258) que criminalizava relações homossexuais entre homens: "Os atos libidinosos entre indivíduos do sexo masculino serão reprimidos, quando causarem escândalo público, impondo-se a ambos os participantes detenções de até um ano" (GREEN \& POLITO, 2004: 96). O artigo 258 não entrou em vigor. Entretanto, explicita o desejo de reprimir e punir os atos que atentassem contra a moral hegemônica. Uma das razões possíveis para seu insucesso em tornar-se norma legal é que o encarceramento dessa população proporcionaria um reexame dos postulados do direito penal. Contudo, ainda que não estivessem assentados nesse dispositivo legal, os processos de captura da homossexualidade encontravam respaldo na racionalidade criminológica vigente, que prezava pela minuciosa análise biopsicológica - nesse caso análises das ditas anormalidades hormonais - como parte do processo de psicopatologização do então denominado homossexualismo (FERLA, 2005).

Jorge Jaime, romancista carioca, produziu obras que versavam sobre a homossexualidade. Ainda que não estivessem no âmbito da criminologia, ilustravam a racionalidade da época ao alocar a homossexualidade no grupo que detinha predisposição ao crime. Na obra Homossexualidade Masculina, de 1950, ele escreve:

A sodomia trouxe e trará sempre consigo os germens da doença, da tragédia, do crime. Não se iludam, jovens adolescentes. Quando lhes falarem de "uma felicidade celeste", de um "gozo imortal", não acreditem. Eu vi a outra face do "Amor Socrático" e lhes asseguro que é horrenda, monstruosa (...). O pederasta é um criminoso consumado. Atenta contra a moral pública nos cinemas, rouba nas casas comerciais, assassina nos quartos fechados e usa de meios secretos para perpetrar injúria, difamação e calúnia. A imprensa diária constantemente assinala homicídios em que homossexuais passivos morrem estrangulados nas mãos dos homens que lhes extorquem o dinheiro, e rapazes são esfaqueados por sodomitas ciumentos. (JAIME, 1950, citado por GREEN \& POLITO, 2004: 93)

Não coincidentemente, o mesmo autor manifesta a necessária reeducação psicológica nesses casos, através de clínicas e dispositivos de educação sexual que preservassem o código moral delineado a partir da heterossexualidade (GREEN \& POLITO, 2004).

Leonídio Ribeiro, a partir das ideias de Lombroso, lança-se no estudo da biotipologia dos homossexuais (GREEN \& POLITO, 2004). Entretanto, para ele a homossexualidade não deveria ser punida criminalmente. O autor acreditava que o indivíduo homossexual apresentaria em sua formação biológica os elementos geradores da homossexualidade, e por isso o "tratamento" deveria substituir a penalidade jurídica. Em uma conferência realizada em 24 de abril de 1937, Ribeiro discutiu essa questão:

No século passado foi que o problema do homossexualismo começou a ser estudado por médicos e psyquiatras, interessados em descobrir suas causas, a fim de que os juristas e sociólogos pudessem modificar as legislações existentes, todas baseadas em noções empíricas 
$e$ antigos preconceitos. As práticas de inversão sexual não podiam continuar a ser consideradas, ao acaso, como pecado, vício ou crime, desde que se demonstrou tratar-se, na maioria dos casos, de indivíduos doentes ou anormaes, que não deviam ser castigados, porque careciam, antes de tudo, de tratamento. A medicina havia libertado os loucos das prisões. Uma vez ainda, seria ella que livraria da humilhação esses pobres indivíduos, victimas de suas taras e anomalias. (RIBEIRO, 1937, p. 60)

Convém ressaltar o papel, que para ele, caberia à medicina. Em sua visão, o saber médico salvou os loucos e agora deveria estender o "benefício" para os homossexuais. O alegado benefício consistia na marcação de uma degeneração a ser combatida por meio das intervenções médicas. Leonídio Ribeiro foi influenciado principalmente pelas obras do médico espanhol Gregório Marañon, que debatiam o papel da endocrinologia na homossexualidade. Marañon foi um dos precursores da ideia de que as mulheres e os homens detêm tanto os hormônios masculinos como os femininos, com diferentes quantidades, que definiriam o sexo de cada um. No caso dos homossexuais, afirmava haver alterações nessa distribuição, originando o que Ribeiro também chamou de inversão sexual: "Marañon encontrou a disposição feminina do systema piloso em $75 \%$ dos homossexuais por elle examinados, isto é, escassez de pelos no tronco e membros, implantação anormal dos cabelos na nuca e na fronte, além do atraso do aparecimento do bigode, assim como insufficiencia de barba". (RIBEIRO, 1937: 63)

O livro Homossexualismo e Endocrinologia, de 1938, apresenta a pesquisa realizada por Ribeiro, na qual 195 homossexuais foram catalogados e analisados de acordo com as características corporais e aspectos endocrinológicos. A pesquisa foi mais uma demonstração da ampla articulação entre o aparato policial e o saber médico. A análise dos indivíduos, nas palavras de Ribeiro, contou com a "boa vontade" do delegado auxiliar da Polícia do Rio de Janeiro, Dr. Dulcídio Gonçalves, responsável pelo recolhimento dos sujeitos pesquisados - isto é, detenção e encarceramento (RIBEIRO, 1938, citado por GREEN e POLITO, 2004).

A análise do médico mensurou diversos aspectos corporais, como o comprimento dos membros superiores e inferiores, peso corporal e a distribuição dos pelos em diferentes partes do corpo. Em menor dimensão, também classificou aspectos sociais como os ofícios exercidos pelos indivíduos. Destaca-se a divisão realizada entre os homossexuais "confessos" e "não confessos", na qual 183 homens integravam o primeiro grupo e 12 formavam o segundo. A confissão, termo empregado nos âmbitos jurídico e religoso, relaciona-se com a culpa e responsabilização diante de um crime ou pecado. O estudo realizado por Ribeiro, dentro de uma esfera médica, reverberou a linguagem jurídica e religiosa e explicitou o imbricamento existente entre os saberes. Também há a menção dos aspectos endocrinológicos, tão presentes no discurso de Ribeiro: 
Em dois terços dos casos por nós estudados havia ao menos um sinal de distúrbios de natureza endócrina, revelando principalmente alterações das glândulas genitais e supra-renais. Todos os casos por nós examinados podem ser incluídos, na classificação de Marañón, dentro do grupo de indivíduos de homossexualidade declarada, cuja libido está francamente invertida, desde os começos de sua atividade sexual. (RIBEIRO, 1938, citado por GREEN \& POLITO, 2004: 99)

O estudo de Leonídio Ribeiro articula-se com a vontade de curar, pois coisifica sujeitos que destoam da heterossexualidade. Tal experimento objetivou a classificação e análise de sujeitos a partir da ideia de que a homossexualidade resultava da desregulação do sistema endocrinológico. Dessa forma, o estudo resultou em terapias hormonais que geralmente ocorriam em caráter compulsório. Merece destaque que os sujeitos deste estudo integravam uma população carcerária e estiveram institucionalmente capturados para as intervenções da medicina. A vontade de curar, que subjuga os que fogem à norma, exprime-se nesse caso.

A perspectiva psiquiátrica explicitada por Ribeiro, embora majoritária, não era a única. Em 1939, Gualter Adolpho Lutz lançou a obra Auto-Acusação, Homossexualismo e Transvestitismo: Contribuição à Prática da Criminologia Psicanalítica. Abordando um caso jurídico de auto-acusação, Lutz adentrou na discussão sobre a homossexualidade e o crime a partir de uma análise psicanalítica. Não há em sua obra articulação entre a homossexualidade e a degenerescência; apesar disso, Lutz apresenta uma explicação para a homossexualidade, defendendo que esta é uma problemática psíquica, assim como as motivações para o crime que analisa em sua obra. Lutz valoriza os estudos sobre as gêneses biológicas da homossexualidade, mas afirma que “(...) é preciso ter em conta que a psique também influe sôbre as vísceras, não acontecendo apenas o inverso" (LUTZ, 1939, p. 197). Dessa forma, ele defendeu que o saber psicanalítico poderia subsidiar a Criminologia ao apresentar prognósticos que promoveriam decisões judiciais mais acertadas. Para ele, isso asseguraria a proteção da sociedade e impediria sentenças imoderadas que atentassem contra o direito à liberdade (LUTZ, 1939). Evidencia-se, novamente, a ampla conexão entre o campo jurídico e os saberes psi: "Por isso mesmo, seria desejável que se aplicassem todos os recursos da técnica na colheita de subsídios científicos orientadores do Juiz, que deles se utiliza na imposição de medidas de segurança e na dosagem da pena dentro dos limites.” (LUTZ, 1939: 167)

Cabe destacar o olhar de Lutz acerca da proteção dos direitos civis. No caso jurídico analisado em seu livro, há a sustentação de um olhar que destoava dos demais olhares sobre os criminosos. Lutz não desresponsabilizava o crime, mas detinha sua atenção nos aspectos que poderiam explicá-los a partir da psicanálise e defendia o tratamento humanizado para esses sujeitos. Apesar disso, em sua obra também há argumentos sobre a possível reversão da homossexualidade. 
Encontrar-se-á a existência fundamental de múltiplas possibilidades de evolução libidinal, barradas em algumas direções por circunstâncias da evolução libidinal do examinado. Assim sendo, não é impossível a readaptação desses anormais. É verdade que também não é muito fácil, pelo pouco desejo de modificações inerente aos pervertidos, por mais que afirmem o contrário. É que eles se acham apegados ao prazer que tiram da sua aberração. Além disso, havendo narcisismo, como é habitual no homossexualismo, êles se acham satisfeitos com a sua personalidade, não nutrindo o desejo de modificá-la. (LUTZ, 1939, p. 198).

É inegável a discrepância entre Gualter Lutz e Leonídio Ribeiro. Enquanto este buscava a gênese universal da homossexualidade, aquele detinha-se sobre os aspectos que compunham as realidades psíquicas individuais. Lutz pregava a necessidade de análises profundas em detrimento de olhares que catalogariam sujeitos distintos em um mesmo grupo. Contudo, ambos compartilhavam a perspectiva da cura para a homossexualidade a partir do olhar da normatização social dos corpos, que os dividia entre normais e anormais.

Os estudos realizados na década de 1930 careceram de rigor científico e não conseguiram sustentar, metodologicamente, que a homossexualidade e a transexualidade advinham simplesmente dos aspectos biotipológicos. Apesar disso, os estigmas decorrentes da tentativa de relacionar a homossexualidade com a degenerescência permanecem atravessando a vivência desses indivíduos. Já no discurso de Lutz sobre a homossexualidade o envolvimento do médico psicanalista no caso jurídico mencionado confirma o lugar de destaque oferecido ao conhecimento sobre o psiquismo na esfera da criminologia. Uma vez introduzido na esfera do estudo sobre o criminoso, tal conhecimento desdobra-se no campo sócio-cultural, tendo em vista a influência da criminologia no senso comum. A partir disso, é possível compreender alguns dos enlaces discursivos pelos quais a psicologia tem sido convidada a falar novamente sobre a suposta "gênese da homossexualidade".

\section{Considerações Finais}

As tecnologias de poder sobre a sexualidade têm ganhado espaço privilegiado nos debates públicos no Brasil, o que também inclui um debate interno e externo à psicologia. Hodiernamente, alguns psicólogos apoiam a possibilidade da cura-gay, alinhados com a crescente onda de conservadorismo no Brasil. Em posição contrária aos princípios do código de ética da profissão, oferecem tratamento para a reorientação sexual e ocupam espaços de poder na defesa das posições. Numa estranha fusão entre seus lugares sociais como psicólogas/os e pastoras/es, tal grupo afirma um projeto de "psicologia cristã", que usurpa o lugar de fala da psicologia como ciência e profissão, enquanto opera a lógica da normatização 
moralizadora religiosa e angaria força em seu projeto de poder político. Os "pastores da cura" assim reeditam as teses médicas e criminológicas que capturaram a homossexualidade como desvio a um só tempo da moral, da lei e da saúde.

Merece reflexão a captura delineada por esses profissionais para a sustentação da homossexualidade enquanto patologia. Os argumentos que defendiam a repatologização da homossexualidade nos discursos dos sujeitos que atuaram nos trâmites parlamentares em que se discutiu a atuação dos psicólogos no tratamento da homossexualidade entre 2009 e 2010 estiveram assentados nas seguintes associações: homossexualidade e patologia, homossexualidade e imoralidade, homossexualidade e pedofilia, e homossexualidade e práticas criminosas (GAMA, 2019). Tais argumentos estão totalmente articulados com o pensamento difundido pela criminologia na década de 1930, fazendo pensar em como os discursos se recriam a partir das possibilidades de enunciação.

Os trâmites parlamentares também evidenciaram o uso de discursos de verdade na disputa em voga. Foucault (1996) apresenta a vontade de verdade como o anseio de produzir e fazer com que se reproduzam discursos verdadeiros. Tais discursos são receptáculos de normatizações instituídas que não enfrentam resistência ao serem enunciadas. Os especialistas, detentores do saber-poder, tornam-se sujeitos privilegiados nas interações que envolvem temas próprios de suas esferas de conhecimento. Enquanto guardiões dos saberes, o que enunciam reverbera como discurso de verdade, subjugando discursos não científicos. A presença da psicóloga Marisa Lobo e do psicólogo Silas Malafaia foi uma estratégia para o fortalecimento da pretensa legitimação do suposto tratamento de homossexuais. A vontade de verdade é enunciada partir da captura do saber psicológico na tentativa de autenticar os discursos enunciados. Assim, é possível observar o peso do discurso psicológico quando este é capturado em prol de ideias que coisificam os indivíduos.

Os debates parlamentares aqui comentados também pareceram perseguir o objetivo de intervir nas manifestações sexuais através da prática psi a partir da vontade de normatizar e de impedir fluxos que se estendam para além do tecido controlado pelos códigos hegemônicos. A matriz familiar pai-mãe-filho é considerada a base do modelo de sociedade capitalista, sendo responsável pela transmissão da moral vigente desde os primeiros momentos de vida. Além disso, a família inserida no mundo neoliberal será enquadrada em uma lógica empresarial na qual a relação familiar será analisada a partir dos investimentos que ocorrem no meio intrafamiliar em harmonia com a produtividade social (FOUCAULT, 2008b, p. 331). Em uma racionalidade econômica, modelos familiares dissidentes representam rupturas no tecido social dominante e, a partir deste olhar, tornam-se eminentemente perigosos. 
A prática profissional do psicólogo, ainda que esteja calcada em uma norma ética, é atravessada por desígnios externos que tentam capturá-la enquanto discurso de saber-poder. Assim sendo, os profissionais psi precisam atentar-se para tais tentativas e fortalecer o compromisso ético da psicologia de continuar oferecendo acolhimento para as múltiplas potencialidades presentes em cada indivíduo. O conhecimento sobre a subjetividade humana é capaz de subsidiar diversas ações e intervenções. Por isso, compreender os lugares oferecidos aos psicólogos constitui uma tarefa indispensável para atuações profissionais que coadunem com a ética da profissão. A laicidade da psicologia e do Estado não é um acontecimento encerrado, e sim um acontecimento imerso num campo de forças. Na atual conjuntura do Brasil, onde atravessamentos morais religiosos operam nas discussões sobre a esfera pública, comprometer-se com a defesa dos direitos humanos significar atuar politicamente em defesa das multiplicidades, singularidades e do tecido coletivo, colaborando, dessa forma, para a construção de trajetórias potentes.

\section{Referências}

BAREMBLITT, Gregorio. F. Compêndio de análise institucional e outras correntes: teoria e prática. Rio de Janeiro: Rosa dos tempos, 1996.

BETHELL, Leslie. O Brasil no mundo. In:, J. M. Carvalho (coord.). História do Brasil Nação (1808-2010) - volume 2 - A construção nacional (1830-1889) (pp.131-178). Rio de Janeiro: Objetiva, 2012.

CARVAlHO, José Murilo de. Cidadania no Brasil: o longo caminho Rio de Janeiro: Civilização Brasileira, 2008.

CERTEAU, Michel de. A escrita da história. Rio de Janeiro: Forense Universitária, 1982.

CHÂTELET, François. Uma História da Razão: Entrevistas com Émile Nöel. Jorge Zahar Editora: Rio de Janeiro, 1992.

CONSELHO FEDERAL DE PSICOLOGIA (CFP). Resolução CFP n. 1/99, estabelece normas de atuação para os psicólogos em relação à questão da orientação sexual, 23 mar. 1999, Brasília, $1999 . \quad$ Disponível em: https://site.cfp.org.br/wpcontent/uploads/1999/03/resolucao1999_1.pdf Acesso 23/04/2020

CONSELHO FEDERAL DE PSICOLOGIA (CFP). Código de Ética Profissional do Psicólogo, Brasília, 2005. Disponível em https://site.cfp.org.br/wpcontent/uploads/2012/07/codigo-de-etica-psicologia.pdf Acesso em 23/04/2020

CONSELHO FEDERAL DE PSICOLOGIA (CFP). Tentativas de aniquilamento de subjetividades LGBTIs. Conselho Federal de Psicologia. - Brasília, DF: CFP, 2019. 220 p. Disponível em https://site.cfp.org.br/wpcontent/uploads/2019/06/CFP_TentativasAniquilamento_WEB_FINAL.pdf Acesso em $\underline{23 / 04 / 2020}$ 
CONSELHO FEDERAL DE PSICOLOGIA (CFP). Caderno de Deliberações do $10^{\circ}$ Congresso Nacional de Psicologia: o (im)pertinente compromisso social da psicologia na resistência do Estado de exceção e nas redes de relações políticas, econômicas, sociais e culturais. Conselho Federal de Psicologia. - Brasília, DF: CFP, 2019. 141 p. Disponível em https://site.cfp.org.br/wpcontent/uploads/2019/09/Caderno delibera\%C3\%A7\%C3\%B5es 10 CNP web 8 outubro F INAL.pdf Acesso em 28/08/2020

DELEUZE, Gilles. Nietzsche e a filosofia. Rio de Janeiro: Editora Rio, 1976.

FERLA, Luis. Feios, sujos e malvados sob medida: a utopia médica do biodeterminismo. São Paulo: Alameda, 2005.

FERRAZ, Maria Cristina Franco. Nietzsche, o bufão dos deuses. Rio de Janeiro: Relume Dumará, 1994.

FOUCAULT, Michel. História da Sexualidade I: a vontade de saber. Trad. M.T. C. Albuquerque e J. A G. Albuquerque. Rio de Janeiro: Graal, 1988.

FOUCAULT, Michel. Ordem do discurso. Edições Loyola, 1996.

FOUCAULT, Michel. Em Defesa da Sociedade. São Paulo: Martins Fontes, 2005.

FOUCAULT, Michel. Nascimento da biopolítica. São Paulo: Martins Fontes, 2008a.

FOUCAULT, Michel. Segurança, Território, População. São Paulo: Martins Fontes, 2008b.

GAMA, Maria Clara Brito da. Cura Gay? Debates parlamentares sobre a (des)patologização da homossexualidade. Sexualidad, Salud y Sociedad (Rio de Janeiro), (31), 4-27. Epub April 30, 2019. Disponível em http://www.scielo.br/scielo.php?script=sci arttext\&pid=S1984-64872019000100004 Acesso em $23 / 04 / 2020$

GREEN, James N. \& POLITO, Ronald. Frescos Trópicos: Fontes sobre a homossexualidade masculina no Brasil (1870-1980) Rio de Janeiro: Editora José Olympio, 2004.

LUTZ, Gualter Adolpho. Auto-Acusação, Homossexualismo e Transvestitismo: Contribuição à Prática da Criminologia Psicanalítica. Rio de Janeiro: Tese apresentada à Faculdade Nacional de Medicina da Universidade do Brasil a fim de inscrever-se no concurso para provimento de cargo de Professor Catedrático de Medicina Legal, 1939.

MARTINS, Karina Oliveira; LACERDA JUNIOR, Fernando. Ideologização da violência no capitalismo: contribuições da psicologia da libertação de Martín-Baró. Gerais, Rev. Interinst. Psicol. [online]. Belo Horizonte, v. 11, n. 2, p. 221-235, 2018. Disponível em $\quad$ http://pepsic.bvsalud.org/scielo.php?script=sci_arttext\&pid=S198382202018000200004\&lng=pt\&nrm=iso. Acesso em 28 ago. 2020. http://dx.doi.org/10.36298/gerais2019110204.

RIBEIRO, Leonidio. Etiologia e tratamento da homossexualidade. Anthropologia criminal: conferências e comunicações. Rio de janeiro: Imprensa Nacional, 1937.

SILVA, Luis Gustavo Teixeira da. Religião e Política no Brasil. Latinoamérica [online]. n.64. 223-256, 2017. Disponível em http://www.scielo.org.mx/scielo.php?script=sci arttext\&pid=S1665-85742017000100223 Acesso em 23/04/2020 
Pastores da cura: historiografia de discursos e intervenções médico-criminológicas sobre a homossexualidade no Brasil (1930-1940). 479

Programa de Pós-Graduação em Psicologia

Universidade Católica de Brasília E-mail: juliana.dasilva.ucb@gmail.com

Luender Rytchell Martins Silva

Universidade Católica de Brasília

E-mail: luender.rytchellms@ gmail.com 